\title{
Suitability of Kibuye Market Organic Waste for Composting as a Means of Solid Waste Management for Kisumu City
}

\author{
John O Oloo, Frankline O Awuor*
}

Department of Natural Resources Management, School of Spatial Planning and Natural Resources Management, Jaramogi Oginga Odinga University of Science and Technology, Kenya

\begin{abstract}
Purpose: Organic waste comprises most of the waste in dumpsites in Kenya and this causes environmental challenges at such sites. With Kisumu as a case study, the purpose of this work was to explore the suitability of organic wastes from Kibuye market, hotels and livestock farms for compost manure making as a means of organic solid waste management.
\end{abstract}

Methods: The study was cross-sectional in design. Compost manure was prepared from organic market waste, hotel food remains and livestock dung. Samples were then taken to a laboratory to test for the content of nitrogen, phosphorous $\left(\mathrm{P}_{2} \mathrm{O}_{5}\right)$ using TES/06/TM/21 and TES/06/TM/24 methods respectively and potassium $\left(\mathrm{K}_{2} \mathrm{O}\right)$ using Atomic Absorption Spectrometry (AAS) method as well as for heavy metals $(\mathrm{Cd}, \mathrm{Cu}, \mathrm{Fe}, \mathrm{Pb})$ while the $\mathrm{Ph}$ of the compost was tested by KS-158 method.

Results: Laboratory tests for the presence of important crop elements were Nitrogen (0.4\%), Phosphorous $(0.4 \%)$, and Potassium (0.9\%) whereas for heavy metals were $\mathrm{Cd}=\mathrm{Nil}, \mathrm{Cu}=10.1, \mathrm{Fe}=1.08, \mathrm{~Pb}=\mathrm{Nil}$, and $\mathrm{pH}=8.4$.

Conclusion: It is safe to use organic waste from Kibuye as augmented by those from hotels and livestock farms for composting as a means of organic solid waste management if other supporting systems are in place.

Keywords: Organic solid waste; Composting; Organic manure; Dumpsites; Heavy metals contaminants; Hotel food waste

\section{INTRODUCTION}

Sustainable Integrated Solid Waste Management (ISWM) is one of the important obligatory functions of any Urban or City authority. It refers to all activities pertaining to the control, collection, transportation, processing, treatment and disposal of wastes in accordance with sustainability principles. The fundamental objective of solid waste management is to protect the health of the public, promote environmental quality, and create employment through a circular economy of waste resources [1]. Many urban centers in Kenya, including Kisumu City, generate a lot of organic matter. However, proper management of such wastes have proved a challenge nationally. Consequently, a larger proportion of such waste end up in drainage channels, open spaces and municipal dumpsites where they are poorly managed thus clogging them [2]. Even though the advantages of organic manure are widely known; advantages which include increasing soil fertility, improving soil physical conditions and microbiological conditions as well as crop yield $[3,4]$, lack of knowledge of their exact nutritive value and possible contaminants deter farmers from utilizing them on their farms. Consequently, they are left to fill dumpsites, be fed on by scavenging livestock and birds or left to decay thereby emitting repugnant odours and greenhouse gases which cause air pollution. These gases contribute to global warming with its attendant environmental hazards. In order to contribute to the mitigation of these effects, this study sought to determine the suitability of organic wastes from Kibuye market for compost manure as a means of solid waste management in Kisumu City. Specifically, this study assessed the nutritive value of such manure and the presence of heavy metal contaminants.

\section{METHODOLOGY}

The study design adopted by this investigation was cross-sectional in nature in that the organic matter used for compost making was only from one season. It was not a year-round exercise. Materials required for composting were measured by a wheelbarrow of $0.045 \mathrm{~m}^{3}$ capacity. The amounts, therefore, were 5 wheelbarrows

${ }^{*}$ Correspondence to: Frankline O Awuor, Department of Natural Resources Management, School of Spatial Planning and Natural Resources Management, Jaramogi Oginga Odinga University of Science and Technology, Kenya, Tel: 0720984254; E-mail: frank.awuor@gmail.com

Received: September 30, 2019; Accepted: November 27, 2019; Published: December 02, 2019

Citation: Oloo JO, Awuor FO (2019) Suitability of Kibuye Market Organic Waste for Composting as a Means of Solid Waste Management for Kisumu City. Int J Waste Resour 9:370. doi: 10.35248/2252-5211.19.9.370

Copyright: @ 2019 Oloo JO, et al. This is an open-access article distributed under the terms of the Creative Commons Attribution License, which permits unrestricted use, distribution, and reproduction in any medium, provided the original author and source are credited. 
of each of the following; 1) vegetable waste, 2) avocado and Irish potato wastes, 3) mango and orange wastes, 4) tomato and carrot wastes, 5) pineapples and green banana peels, and 6) guano. Additional materials were 1 wheelbarrow each of banana peels, and hotel food remains, and, 2 wheelbarrows each of saw dust, and cow dung. In order to make the compost, a secure secluded spot in the market backyard was cleared for the compost heap. Thereafter, the vegetables, avocado and Irish potato, mango and orange, tomato and carrot, pineapples and green banana peels were mixed in a heap and covered with polythene (1000 gauge) to prevent unnecessary moisture, (e.g. from rain) from being added into the mix. This was regularly checked and turned for mixing to realize even decomposition. At four weeks, the guano, saw dust and cow dung were again added and the whole mixture thoroughly mixed for even distribution of the materials and proper composting. The mixture was again covered with polythene and left for three weeks after which it was ready. It was once again mixed for aeration then moved under a shade, covered with polythene, and left for one and a half weeks to dry. Thereafter, it was ground using fabricated grinding machine to achieve homogeneity of grain size. This was repeated two more times so that there were a total of three preparations. Samples from these three preparations were taken to a government facility (Kenya Bureau of Standards [KBS]) to test for nutrient contents (Nitrogen, Potassium and Phosphorous) and the presence of heavy metal contaminants (Cadmium [Cd], Copper $[\mathrm{Cu}]$, Iron $[\mathrm{Fe}]$, and Lead $[\mathrm{Pb}])$ and for its $\mathrm{pH}$ value. The contents of nitrogen and phosphorous were tested using TES/06/TM/21 and TES/06/TM/24 methods respectively while for Potassium was tested using Atomic Absorption Spectroscopy (AAS) method as well as for the heavy metals. The testing standards were according KBS criteria KS 2356:2012 for nutrients and KS 2290 for the heavy metals. $\mathrm{pH}$ was measured using the KS-158 method. Additional information about the feasibility of composting as a means of solid waste management in Kisumu was collected by observation.

\section{RESULTS AND DISCUSSIONS}

First, we present and discuss laboratory findings on nutrient content followed by the presence of heavy metal contaminants. Thereafter, we wind up this section with a conclusion and some recommendations.

\section{Nutrient content}

Laboratory tests for nutritive content are as indicated in Table 1. Nitrogen and phosphorous $\left(\mathrm{P}_{2} \mathrm{O}_{5}\right)$ content were $0.4 \%$ of the sample mass while for potassium was $0.9 \%$. These nutrient contents are not static but expected to vary with different proportions of and types of brown and green matter for composting. These findings are, however, important as a point of information for farmers that would want to apply this organic manure on their farms. Moreover, these lab results can inform efforts to augment the compost with inorganic fertilizer in order to meet specific soil and plant nutrient requirements; a practice that is recognized by other studies [5]. This further helps allay farmers fears, as we have noted

Table 1: Percentage availability of nitrogen, phosphorous and potassium in the compost made from Kibuye market organic waste.

\begin{tabular}{lcc}
\hline Parameter & Results $(\% \mathrm{~m} / \mathrm{m})$ & Test method \\
\hline Nitrogen Content & 0.4 & TES $/ 06 / \mathrm{TM} / 21$ \\
\hline Phosphorous as $\mathrm{P}_{2} \mathrm{O}_{5}$ & 0.4 & TES $/ 06 / \mathrm{TM} / 24$ \\
\hline Potassium as $\mathrm{K}_{2} \mathrm{O}$ & 0.9 & AAS \\
\hline
\end{tabular}

locally, that in buying or making composts, they are not sure the nutrient composition is suitable for their soil and plant needs. The greatest nutrient benefit of compost, nevertheless, is that it releases nutrients over a long period of time as it further decays thus reducing the need to continually fertilize soils.

Composting holds the promise of providing a sustainable management solution to the $60-65 \%$ organic waste [6] that usually comprise the waste at Kachok dumpsite, a dumpsite that is currently being relocated. However, a number of challenges still stand in the way of this realization. Notable among these obstacles are that organic wastes are not separated at source and urban residences are too small to manage them within their compounds as also observed in Uganda [7]. Furthermore, the City does not have composting spaces in its solid waste management dumpsite at Kachok. If the City solves these bottlenecks in its future strategies for solid waste management, then the one hurdle that will remain is to create demand for the compost by farmers.

\section{Presence of heavy metal contaminants}

Lab results indicate that the compost was free from Lead and Cadmium contamination. The content of Iron and Copper were at $1.08 \% \mathrm{~m} / \mathrm{m}$ and $10.1 \mathrm{mg} / \mathrm{Kg}$ respectively. The value of Iron was slightly above the minimum quantity $(10 \mathrm{mg} / \mathrm{kg})$ required in soils [8] while that of Copper was way below the threshold value $(100 \mathrm{mg} / \mathrm{kg})$ according European Standards [9]. These results indicate that the compost is free from heavy metal contamination and thus suitable for farming as a waste management strategy. These values are most likely due to the fact that they were separated at source and that sludge was not used. Had they been sourced from sludge or the City's dumpsite, they could perhaps have been contaminated by chemicals from medicines, pesticides, and other polluting substances (e.g from electronics) that find their way into sewerage systems or get dumped at dumpsites [10]. Organic wastes from markets and hotels, when captured at source, often escape this contamination. Even though heavy metals occur naturally in the environment, when their concentrations exceed a certain limit, they become toxic to plants and humans.

The availability of heavy metals for plant uptake and the actual uptake by plants is greatly a function of soil $\mathrm{pH}$ besides other factors such as plant absorption and metabolism characteristics [11]. Studies indicate that the lower the $\mathrm{pH}$ value, the more available heavy metals are for plant uptake $[12,13]$. Our findings indicated that the $\mathrm{pH}$ for the compost was 8.4 , which is within the acceptable range (6.5-8.5) for most plants to grow and limit the availability of heavy metals according to Kenyan standards. Even though pH may fluctuate in soil overtime, the value of our compost is suitable for farms and limits the availability of heavy metals for plant uptake in a manner not to cause toxicity (Table 2) [14-16].

\section{CONCLUSION AND RECOMMENDATIONS}

Since the compost manure was free from heavy metal pollution according to Kenyan and International standards, it can be utilized as a means of solid waste management in Kisumu City. This will have the triple advantage of: 1) sustainably managing organic solid waste which comprise the greater percentage of solid wastes reaching Kisumu's dumpsite, 2) creating business and 3) improving food production through improved soil quality in the region. This is particularly important noting that a greater proportion the organic waste reaching the dumpsite comes from Kibuye market and 
Table 2: Laboratory results for heavy metal content present in Kibuye market solid waste.

\begin{tabular}{lcccc}
\hline Parameter & Units & Results & $\begin{array}{c}\text { Kenya Bureau of Standards (KS 2290) } \\
\text { Standard Requirements }\end{array}$ & Test Method \\
\hline Cadmium as $\mathrm{Cd}$ & $\mathrm{mg} / \mathrm{kg}$ & Not detected & $5 \mathrm{Max}$ & AAS \\
\hline Copper as $\mathrm{Cu}$ & $\mathrm{mg} / \mathrm{kg}$ & 10.1 & $300 \mathrm{Max}$ & AAS \\
\hline Iron Content & $\% \mathrm{~m} / \mathrm{m}$ & 1.08 & $0.1 \mathrm{Min}$ & AAS \\
\hline Lead as $\mathrm{Pb}$ & $\mathrm{mg} / \mathrm{kg}$ & Not detected & $30 \mathrm{Max}$ & AAS \\
\hline $\mathrm{PH}$ & & 8.4 & $6.5-8.5$ & KS-158 \\
\hline
\end{tabular}

hotels. Their utilization for compost making, therefore, is a viable and promising way to sustainably manage them. Furthermore, almost all of the city's waste can be managed this way if separation at household can be achieved, as is recommended by other studies. Already, the City, through its manager, Doris Ombara, has indicated that the City plans to manage its organic waste through composting and biodigesters. However, in order for such initiatives to succeed, as the objective of this study envisions, further steps need to take place. Such include waste separation at source to avoid contamination, awareness creation among farmers regarding the importance of compost or organic manure, regular testing of compost for nutrient content and possible contamination, creation of space(s) for composting at the City level and proper marketing of the composts.

\section{ACKNOWLEDGEMENT}

This study was financially supported by Mistra Urban Futures (MUF) through its Kisumu Local Interactions Platform (KLIP). We also wish to appreciate the field support of Kibuye CBO in Kibuye market, Kisumu City.

\section{REFERENCES}

1. Henry RK, Yongsheng Z, Jun D. Municipal solid waste management challenges in developing countries-Kenyan case study. Waste management. 2006;26:92-100.

2. Awuor FO, Nyakinya B, Oloo J, Oloko M, Agong SG. How did Kachok dumpsite in Kisumu City develop into a crisis? In Urban Forum. Springer Netherlands. 2019;30:115-131.

3. De Datta SK, Hundal SS. Effects of organic matter management on land preparation and structural regeneration in rice based cropping systems. IRRI, Philippines. 1984;399-417.

4. Ingelmo F, Molina MJ, Soriano MD, Gallardo A, Lapeña L. Influence of organic matter transformations on the bioavailability of heavy metals in a sludge based compost. Journal of environmental management. 2012;95:S104-S109.

5. Harrison RB. Composting and formation of humic substances. Encyclopedia of Ecology. 2008.
6. Munala $G$, Moirongo BO. The need for an integrated solid waste management in Kisumu, Kenya. Journal of Agriculture Science and Technology. 2011;13:65-79.

7. Nsimbe P, Mendoza H, Wafula ST, Ndejjo R. Factors Associated with Composting of Solid Waste at Household Level in Masaka Municipality, Central Uganda. Journal of environmental and public health. 2018.

8. Westfall DG, Bauder TA. Zinc and Iron Deficiencies. 2014.

9. Tóth G, Hermann T, Da Silva MR, Montanarella L. Heavy metals in agricultural soils of the European Union with implications for food safety. Environment international. 2016;88:299-309.

10. Mandal P, Chaturvedi MK, Bassin JK, Vaidya AN, Gupta RK. Qualitative assessment of municipal solid waste compost by indexing method. International Journal of Recycling of Organic Waste in Agriculture. 2014;3:133-139.

11. Tangahu BV, Abdullah S, Rozaimah S, Basri H, Idris M, Anuar N, et al. A review on heavy metals ( $\mathrm{As}, \mathrm{Pb}$, and $\mathrm{Hg}$ ) uptake by plants through phytoremediation. International Journal of Chemical Engineering. 2011.

12. Zeng F, Ali S, Zhang H, Ouyang Y, Qiu B, Wu F, et al. The influence of $\mathrm{pH}$ and organic matter content in paddy soil on heavy metal availability and their uptake by rice plants. Environmental pollution. 2011;159:84-91.

13. Singh R, Gautam N, Mishra A, Gupta R. Heavy metals and living systems: An overview. Indian journal of pharmacology. 2011;43:246.

14. Hussain F, Chaudhry, MN, Batool SA. Assessment of key parameters in municipal solid waste management: a prerequisite for sustainability. International Journal of Sustainable Development \& World Ecology. 2014;21:519-525.

15. Gautam SP, Bundela PS, Pandey AK, Awasthi MK, Sarsaiya S. Composting of municipal solid waste of Jabalpur City. Global Journal of Environmental Research. 2010;4:43-46.

16. Kumar S. Composting of municipal solid waste. Critical Reviews in Biotechnology. 2011;31:112-136. 